\title{
Phytochemical Screening of leaf extract of Syzygium Cumini L. by HRLC-MS Spectra Method
}

\author{
Satpute S. B. ${ }^{1}$, Vanmare D.J. ${ }^{2}$ \\ ${ }^{1}$ Department of Biology, Shiv Chhatrapati College, N- 3, Cidco, Aurangabad, Maharashtra, India \\ 2Department of Botany, Vivekanand Arts, Sardar Dalipsingh Commerce and Science College, \\ Samarthnagar, Aurangabad, Maharashtra, India
}

\section{ABSTRACT}

By using HRLC-MS spectra method, Phytochemical screening of leaves of Syzygium cumini L. were carried out. It is highly sensitive and used for rapid identification of bioactive compounds. These mass spectra are fingerprint of that compound which can be identified from the data library. It may be the first report of its kind to analyze the bioactive compounds of Syzygium cumini L. The phytochemical study indicates the presence of important bioactive compounds which can be used to treat many diseases in medical field. Phytochemical analysis of methanolic leaf extract of Syzygium cumini L. spectrum profile shows total 80 compounds, out of that 19 major compounds were confirmed on the basis of their retention time, mass, molecular formula and mass per charge ratio $(\mathrm{m} / \mathrm{z})$. The findings of this study suggested that, Syzygium cumini L. is a source of important bioactive compounds. It may be contributing natural antimicrobial, antioxident, anti-inflammentary activity and further investigations which may lead to the development of drug formulation.

Keywords : Syzygium cumini, Phytochemical, antioxident, anti-inflammentary activity, soxhlet and bioactive.

\section{INTRODUCTION}

In number of plants, Phytochemicals are existing in their biologically active forms in healthy plants, but others occur as inactive precursors and were activated in response to tissue damage or pathogen attack Osbourne, 1996. Phytochemicals are naturally present in the plants and play significant role to defend themselves against various pathogenic microbes by showing the antimicrobial activity by inhibition or killing mechanisms. These compounds were varying from plant to plant, some produce large and some produce in small quantity. Recently plant-derived substances became great interest to know their various applications (Baris, 2006). Ethno pharmacologists, botanists, microbiologists, and natural-product chemists are searching the earth for phytochemicals which could be developed for the treatment of infectious diseases (Tanaka, 2006) especially in drugresistant microorganisms and to produce more effective antimicrobial agents.

Syzygium cumini L. Popularly known as "jambolao" is one of the most commonly medicinal plants used to treat diabetes mellitus in Brazil (Teixeira, 2000). Seeds, bark, fruit and leaves have been used in traditional medicine as a remedy for diabetes mellitus in many countries (Rahman, 1989; Teixeira, 1997). Leaves are used in strengthen the teeth and gums, to treat leucorrhoea, stomachalgia, fever, strangury, dermopathy (Warrier 1996), constipation and to inhibit blood discharges in the faeces (Bhandary, 1995).

Many workers were studied that in some plants there are many components such as peptides, aldehydes, alkaloidal constituents, some essential oils, phenols 
and water, ethanol, chloroform, methanol and butanol soluble compounds (Rukshana, 2017; Kakad, 2013). Such compounds being biodegradable and selective in their toxicity are considered valuable for controlling some plant diseases. Abhishek (2011) focused on the potential phytochemicals and pharmacological activity of Syzygium cumini. Various parts of plant including seeds, bark, leaves and fruits had been studied and investigated for various pharmacological properties. The phytochemicals like malieic acid, oxalic acid, gallic acid, tannins, cynidin glycoside, oleanolic acid, flavonoids, essential oils, betulinic acid, friedelin have been reported for significant, antianaemic, gingivititis, antidiarrhieal, antipyretic, antibacterial, antineoplastic, antiinflammetry, hypoglycemic, gastro protective and hypolipidemic properties. Keeping this in view, Phytochemical analysis of leaves of Syzygium cumini L. were carried out by using HRLC-MS spectra method.

\section{METHODS AND MATERIAL}

\subsection{Preparation of sample:}

From Shendra MIDC, Aurangabad (MS), fresh and healthy leaves of Syzygium cumini L. was collected. The leaves were collected in sterile polythene bags and brought to the laboratory and washed with running tap water. These were dried in shade at room temperature till it gets constant weight. The dried material were crushed in mortar - pestle and then in mixture grinder to make fine powder.

\subsection{Preparation of extracts:}

The prepared powder samples were filtered through muslin cloth and $25 \mathrm{gm}$ of fine powder were extracted with methanol as a solvent by using soxhlet extractor for 18 hours at $65^{\circ} \mathrm{C}$. These extracts were filtered through Whatman filter paper no. 42 and concentrated at $40^{\circ} \mathrm{C}$ by using an evaporator and store in umber bottle at $4^{\circ} \mathrm{C}$. These extract were send for HR-LCMS (High Resolution Liquid Chromatography and Mass Spectroscopy) analysis to Sophisticated
Analytical Instrumentation Facility, Indian Institute of Technology, Powai, Mumbai, India, for the detection of various phytochemicals.

\subsection{HRLC-MS analysis:}

At SAIF, IIT Powai, Mumbai, equipment and conditions Identification of metabolites from an active sub-fraction of methanol extract was carried out. Samples were analyzed on a LC-ESI-Q-TOF-MS (Agilent Technologies 6550 i-Funnel) system equipped with a G4220B pump, G4226A auto sampler and G1316C, and a diode array detector (DAD). The elution solvent consisted of a gradient system of $0.1 \%$ formic acid in water (A) and acetonitrile (B) at a flow rate of $0.3 \mathrm{ml} / \mathrm{min}$. The gradient system started with 95\% A: 5\% B reaching 5\% A: 95\% B in 50 min. then back to initial composition $95 \%$ A: $5 \%$ B in $10 \mathrm{~min}$ which was held at same composition for $5 \mathrm{~min}$. The MS analysis was carried out by ESI positive ionization mode. MS source conditions were as follows: capillary voltage $3500 \mathrm{~V}$, Gas temperature $250 \mathrm{C}$, drying gas flow $13 \mathrm{~L} / \mathrm{min}$, sheath Gas temp 300, sheath Gas Flow 11, nebulizing gas pressure 35 (psig), fragmentor 175 V, Skimmer $65 \mathrm{~V}$, Octopole RF Peak $750 \mathrm{~V}$, and mass range $\mathrm{m} / \mathrm{z}$ 50-1000. The resolution was 40,000 FWHM. Metlin database was used to structure confirmation.

\section{RESULTS AND DISCUSSION}

The results are relevant to HRLC-MS analysis of methanolic leaf extract of Syzygium cumini L. spectrum profile (fig.1) shows total 80 compounds present. Out of that 19 major compounds were confirmed on the basis of their retention time, molecular formula and mass. These active compounds are presented in Table 1. The chemical profile of Syzygium cumini L. was characterized by using HRLC-MS spectra. The relative concentrations of various compounds getting eluted as a function of retention time gives in chromatogram. The relative concentration of the bioactive compounds present in the plants was indicated by the height of peak. The 
mass spectrometer analyzes the compounds eluted at different times to identify the nature and structure of the compounds. These mass spectra are fingerprint of that compound which can be identified from the data library. This report is the first of its kind to analyze the bioactive compounds of Syzygium cumini L. using HRLC-MS.

The present investigation revealed the presence of bioactive compounds analysis by HRLC-MS. This study also helped to identify the formula and structure of biomolecules which can be used as natural fungicides. The phytochemical study of Syzygium cumini L. using HRLC-MS indicates the presence of fatty acids, organic compounds, phenolics, alkaloids, phytoharmone, coenzyme, aminopyrimidines, dipeptide and tripeptides like important metabolites in these leaves. These results suggested to do further investigations which may lead to the development of drug formulation

This result was confirmed by many authors. Gowri and Vasantha (2010) studied phytochemical screening and antibacterial activity of Syzygium cumini (L.) leaves extracts. Ugbabe (2010) evaluated the phytochemical, antimicrobial and acute toxicity of the leaf and stem bark extracts of Syzygium cumini Linn. grown in Abuja, Nigeria. The phytochemical screening revealed the presence of carbohydrates, saponins, tannins, terpenes, volatile oil, sterols, resins balsam, phlobatanins and flavonoids in the leaves and stem bark

Chaudhary and Mukhopadhyay (2012) observed that Syzygium cumini (L.) is rich in phytochemicals like glycoside jambolin, anthocyanins, tannins, terpenoids, gallic acid and various minerals. Muniappan and Pandurangan (2012) reviewed phytochemical constituents and traditional uses of Syzygium cumini (L.).The plant is rich in compounds containing anthocyanins, glucoside, ellagic acid, isoquercetin, kaemferol and myrecetin. The seeds contain alkaloid, jambosine, and glycoside jambolin or antimellin, which halts the diastatic conversion of starch into sugar. The leaves are rich in acylated flavonol glycosides, quercetin, myricetin, myricitin, myricetin 3-O-4-acetyl-L-rhamnopyranoside, triterpenoids, esterase, galloyl carboxylase and tannin.

Kadam(2013) evaluated Biochemical of leaves, wood and bark of Syzygium cumini, Butea monosperm, Madhuca indica and Mimusops elengi plants. Prateek (2015) studied antimicrobial activity of Syzygium cumini (L.) fruit and leaf extract against bacterial strains such as Staphylococcus aureus, Staphylococcus saprophyticus, Escherichia coli, Pseudomonas aeurioginosa, Roultella plantikola and fungal strains namely Aspergillus niger, Penicillium chrysogenum, Candida albicans, Fusarium solani. They reported antibacterial activity against all used bacteria. Maximum zone of inhibition was observed for Roultella plantikola and minimum zone of inhibition was observed against Pseudomonas aeruginosa by using fruit extract. The plant extract shown maximum zone of inhibition against fungal strains Penicillium chrysogenum and minimum against Candida albicans. Conclusively they demonstrated that Syzygium cumini(L.) extract possess potential antibacterial and antifungal activity. Imelda and Teresa (2017) evaluatd phytochemical screening of Syzygium cumini leaf extracts using different solvents of extraction.

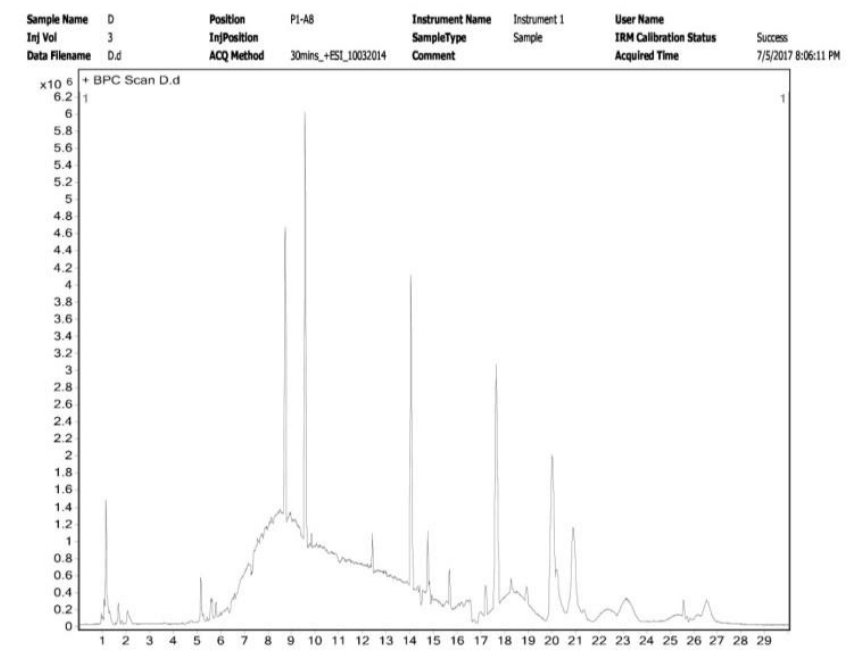

Figure 1 : HRLC-MS Spectrogram of Syzygium cumini $\mathrm{L}$ 
Table 1 : Major phytochemicals from leaves of Syzygium cumini L. by HRLC-MS

\begin{tabular}{|c|c|c|c|c|c|}
\hline $\begin{array}{l}\text { Sr. } \\
\text { No. }\end{array}$ & Name & RT & Mass & Formula & $\mathbf{M} / \mathbf{Z}$ \\
\hline 1 & Ethosuximide M5 & 1.123 & 155.05 & $\mathrm{C}_{7} \mathrm{H}_{9} \mathrm{NO}_{3}$ & 138.05 \\
\hline 2 & Phenyl glucuronide & 5.178 & 270.07 & $\mathrm{C}_{12} \mathrm{H}_{14} \mathrm{O}_{7}$ & 275.05 \\
\hline 3 & Cycloheximide & 5.602 & 281.16 & $\mathrm{C}_{15} \mathrm{H}_{23} \mathrm{NO}_{4}$ & 286.14 \\
\hline 4 & Dihydroptaeroxylin & 5.638 & 260.10 & $\mathrm{C}_{15} \mathrm{H}_{16} \mathrm{O}_{4}$ & 265.08 \\
\hline 5 & 17-phenyl-trinor-PGF2alpha & 5.653 & 388.22 & $\mathrm{C}_{23} \mathrm{H}_{32} \mathrm{O}_{5}$ & 393.20 \\
\hline 6 & 4-(2-hydroxypropoxy)-3,5- dimethyl-Phenol & 7.453 & 196.10 & $\mathrm{C}_{11} \mathrm{H}_{16} \mathrm{O}_{3}$ & 197.11 \\
\hline 7 & Muurolladie-3-one & 8.739 & 218.16 & $\mathrm{C}_{15} \mathrm{H}_{22} \mathrm{O}$ & 201.16 \\
\hline 8 & Propofol & 8.739 & 178.13 & $\mathrm{C}_{12} \mathrm{H}_{18} \mathrm{O}$ & 161.13 \\
\hline 9 & Linalool & 8.740 & 154.13 & $\mathrm{C}_{10} \mathrm{H}_{18} \mathrm{O}$ & 159.11 \\
\hline 10 & 3,7-Epoxycaryophyllan-6- one & 9.852 & 236.17 & $\mathrm{C}_{15} \mathrm{H} 2{ }_{4} \mathrm{O}_{2}$ & 219.17 \\
\hline 11 & $\begin{array}{l}\text { 1-beta,25-dihydroxy-2beta-(3- } \\
\text { hydroxypropoxy)vitamin D3 }\end{array}$ & 12.41 & 490.36 & $\mathrm{C}_{30} \mathrm{H}_{50} \mathrm{O}_{5}$ & 495.34 \\
\hline 12 & $\begin{array}{l}\text { 1-alpha,25-dihydroxy-22-thia-20-epivitamin } \\
\text { D3 }\end{array}$ & 14.04 & 434.28 & $\mathrm{C}_{26} \mathrm{H}_{42} \mathrm{O}_{3} \mathrm{~S}$ & 457.27 \\
\hline 13 & CEDROL & 14.76 & 222.19 & $\mathrm{C}_{15} \mathrm{H}_{26} \mathrm{O}$ & 205.19 \\
\hline 14 & Pro Ala Arg & 15.68 & 342.20 & $\mathrm{C}_{14} \mathrm{H}_{26} \mathrm{~N}_{6} \mathrm{O}_{4}$ & 325.19 \\
\hline 15 & Ramipril glucuronide & 17.65 & 592.26 & $\mathrm{C}_{29} \mathrm{H}_{40} \mathrm{~N}_{22} \mathrm{O}_{11}$ & 593.27 \\
\hline 16 & $\mathrm{~N}$-(2- hydroxyethyl)stearamide & 18.94 & 327.31 & $\mathrm{C}_{20} \mathrm{H}_{41} \mathrm{NO}_{2}$ & 350.30 \\
\hline 17 & Trandolapril glucuronide & 20.02 & 606.28 & $\mathrm{C}_{30} \mathrm{H}_{42} \mathrm{~N}_{2} \mathrm{O}_{11}$ & 607.29 \\
\hline 18 & $\begin{array}{l}\text { 3-beta,6-alpha,7-alpha-Trihydroxy-5-beta- } \\
\text { cholan-24- oic Acid }\end{array}$ & 20.91 & 408.28 & $\mathrm{C}_{24} \mathrm{H}_{40} \mathrm{O}_{5}$ & 413.26 \\
\hline 19 & Methacholine & 25.57 & 160.13 & $\mathrm{C}_{8} \mathrm{H}_{18} \mathrm{NO}_{2}$ & 160.13 \\
\hline
\end{tabular}

\section{CONCLUSION}

The phytochemical study of the leaves of Syzygium cumini L. using HRLC-MS indicates the presence of fatty acids, organic compounds, phenolics, alkaloids, phytoharmone, coenzyme, aminopyrimidines, dipeptide and tripeptides like important bioactive compounds. It may be contributing natural antimicrobial, antioxident, anti-inflammentary activity and further investigations which may lead to the development of drug formulation. 


\section{REFERENCES}

[1]. Abhishek Kumar Sah and Vinod K. Verma (2011). Syzygium cumini: An overview. J. Chem. Pharm. Res. 3(3):108-113.

[2]. Baris, O., Gulluce, M., Sahin, F., Ozer, H., Kilic, H., Ozkan, H., Sokmen, M., Ozbek, T. (2006). Biological activities of the essential oil and methanol extract of Achillea biebersteinii afan (Asteraceae). Turk. J. Biol., 30: 65-73.

[3]. Bhandary, M.J.; Chandrashekar, K.R.; Kaveriappa, K.M. (1995). Medical ethnobotany of the siddis of Uttara Kannada district, Karnataka, India. J. Ethnopharmacol., 47: 149158.

[4]. Chaudhary, B. and Mukhopadhyay, K. (2012). Syzygium cumini (L.) Skeels: A potential source of nutraceuticals. 2(1):46-53.

[5]. Gowri, S.S. and Vasantha, K. (2010). Phytochemical screening and antibacterial activity of Syzygium cumini L. (Myrtaceae) leaves extracts. Int. J. Pharm. Tech. Res. 2:1569157.

[6]. Imelda L. Ramos and Teresa May B. Bandiola (2017). Phytochemical Screening of Syzygium Cumini (Myrtaceae) Leaf Extracts Using Different Solvents of Extraction. Der Pharmacia Lettre, 9 (2):74-78.

[7]. Kadam V.B., Momin R.K., Tambe S.S. and Wadikar M.S. (2013). Biochemical evaluation of some medicinal plants of marathwada region in Maharashtra. Int. J. pharmaceutical res. and bio sci. 2(4):181-188.

[8]. Kakad Subhash, A.S. Wabale and M.N. Kharde (2013). Phytochemical Screening and Antimicrobial Studies on Plumbago zeylanica L. Adv. Biores., 4 (3): 115-117

[9]. Muniappan A. and Pandurangan S. (2012). Syzygium cumini L. Skeels: A review of its phytochemical constituents and traditional uses. Asian. Pac. J. Trop. Biomed. Mar 2(3): 240-246.

[10]. Osbourne, A.E. (1996). Preformed antimicrobial compounds and plant defense against fungal attack. Plant Cell. 8:1821-1831.

[11]. Prateek, A., Meena, R.K. and Yadav, B. (2015). Antimicrobial activity of Syzygium cumini. Ind. J. Applied Res. 5(9):63-66.
[12]. Rahman, A.U.; Zaman, K. (1989). Medicinal plants with hypoglycaemic activity. J. Ethnopharmacol., 74: 217-220.

[13]. Rukshana, M.S., Doss, A. and Kumari Pushpa Rani, T.P (2017). Phytochemical Screening and GC-MS Analysis of Leaf Extract of Pergularia daemia (Forssk) Chiov. Asian J. Pl. Sci. and Res., 7(1): 9-15.

[14]. Tanaka, J.C. A., Da silva, C.C., De OLiveira, A.J.B., Nakamura, C.V. and Dias Filho, B.P. (2006). Antibacterial activity of indole alkaloids from Aspidosperma ramiflorum. Braz. J. Med. Biol. Res., 39(3):387-391.

[15]. Teixeira, C.C.; Pinto, L.P.; Kessler, F.H.P.; Knijnik, L.; Pinto, C.P.; Gastaldo, G.J.; Fuchs, F.D. (1997). The effect of Syzygium cumini (L.) Skeels on post-prandial blood glucose levels in non-diabetic rats and rats with streptozotocininduced diabetes mellitus. J. Etnopharmacol. 56, 209-213.

[16]. Teixeira, C.C.; Rava C.A.; Silva, P.M.; Melchior, R.; Argenta, R.; Anselmi, F.; Almeida, C.R.C.,; Fuchs, F.D. (2000). Absence of antihyperglycemic effect of jambolan in expetimental and clinical models. $\mathrm{J}$. Etnopharmacol. 71, 343-347.

[17]. Ugbabe, G.E, Ezeunala, M.N, Edmond, I.N, Apev, J. and Salawu, O.A. (2010). Preliminary Phytochemical, Antimicrobial and Acute Toxicity Studies of the Stem, bark and the Leaves of a cultivated Syzygium cumini L. (Family: Myrtaceae) in Nigeria. African J. Biotech. 9(41).6943-6947.

[18]. Warrier, P.K.; Nambiar, V.P.K.; Ramankutty, C. (1996). Indian Medicinal Plants. Orient Longman Ltd., Hyderabad. P.225-228. 